\title{
RECENZJE
}

\section{UWAGI O TŁUMACZENIU DIGESTÓW JUSTYNIAŃSKICH TOMASZA PALMIRSKIEGO}

Gdy w 1814 r. Jan Wincenty Bandtkie opublikował w Warszawie łaciński tekst rewizji nowomiejskiej prawa chełmińskiego czyli Jus Culmense Emendatum, wyraźnie podkreślił, że celowo nie dołącza jego przekładu na język polski, gdyż: ,Dzięki niebu żaden prawnik nie ma dotąd beneficium ignorantiae Latinae i nigdy onego mieć nie powinien". I przekonanie to funkcjonowało z okładem sto kilkadziesiąt lat. Dla nikogo jednak nie stanowi tajemnicy, że od tego czasu zmienił się radykalnie nie tylko stopień znajomości łaciny, lecz i stosunek środowiska prawniczego do tego języka. Jeszcze kiedy ja zdecydowałem się pisać pracę magisterską z prawa rzymskiego nikt się nie pytał czy znam łacinę i profesor Osuchowski zaproponował mi temat Elementy prawa rzymskiego $w$ dawnym polskim prawie sadowym $w$ świetle pracy Tomasza Dreznera 'Similium iuris Poloni cum iure Romano centuria una', co oczywiście wymagało wykorzystania tekstów łacińskich, natomiast podczas rozprawy habilitacyjnej kazał przynieść Digesta i ku osłupieniu członków Rady Wydziału zaczęła się zażarta dyskusja w oparciu o teksty źródłowe. Przez długi czas byłem przekonany, że to ja byłem ostatnim, który przechodził przez tego rodzaju aspera, ostatnio jednak usłyszałem, że prof. Marek Kuryłowicz miał podobne przeżycia. Obecnie jednak nikt tego rodzaju praktyk nie kontynuuje ze zrozumiałych względów i nawet sobie tego nie można wyobrazić. Na moim macierzystym Wydziale Prawa i Administracji Uniwersytetu Jagiellońskiego przed kilkunastoma laty ówczesny dziekan Tadeusz Woś doprowadził do zlikwidowania obowiązkowego lektoratu łaciny i przy okazji również ograniczenia roli prawa rzymskiego w strukturze programowej. W ślad za tym postąpił Wydział Filologiczny, a protesty, 
które zgłaszał wybitny erudyta Tadeusz Ulewicz nie na wiele się zdały. Współpracowałem z nim zresztą w tym zakresie, mając jednak pełną świadomość, że nasze głosy to przysłowiowe wołanie na puszczy. Wieść o wycofaniu lektoratu z łaciny ze studiów prawniczych prof. Jan Baszkiewicz skomentował w sposób krótki, ale jakże wymowny: „Czas umierać!”. Ja natomiast doświadczam gorzkiej satysfakcji, gdy słyszę jak promotorzy podczas promocji dukają formułę nadania doktoratu i przeżywają to w większym stopniu aniżeli najbardziej zestresowany doktorant.

W tym stanie rzeczy konieczność dostarczenia współczesnemu prawnikowi polskiego tekstu źródeł prawa rzymskiego nasuwa się sama przez się. Tłumaczenie źródeł ma bowiem stworzyć możliwość bliższego poznania prawa rzymskiego, które ciągle jeszcze stanowi rezerwuar pojęć i instytucji prawnych, mogących znaleźć zastosowanie również $\mathrm{w}$ chwili obecnej. $\mathrm{Z}$ ostatniego okresu wystarczy tu przypomnieć wprowadzenie do polskiego prawa spadkowego legatum per vindicationem, uznane za wyjątkowe osiągnięcie prawa współczesnego, podczas gdy romaniści doskonale wiedzą, że ta instytucja funkcjonowała już w starożytnym Rzymie. To samo można powiedzieć o przywróceniu reguł odpowiedzialności sprzedawcy z tytułu rękojmi za wady fizyczne towaru w duchu zasad wypracowanych przez jurystów rzymskich, a podobne przypadki według wszelkiego prawdopodobieństwa będą miały miejsce również i w przyszłości. Potrzebę tłumaczenia źródeł na języki narodowe odczuwano zresztą jeszcze w okresie, gdy łacina była powszechnie obowiązującą mową uczonych, prawników, urzędników, pisarzy, a nawet poetów. Tak np. pierwszy przekład na język francuski Instytucji justyniańskich pojawił się już w XIII w., a w postaci drukowanej ok. 1485 r. Obecnie istnieją przekłady angielskie, niemieckie, rosyjskie, a nawet chińskie. W Polsce pierwsze tłumaczenie Instytucji Justyniana zostało opublikowane przez Aleksandra Cukrowicza w 1850 r., natomiast kilkanaście lat później to samo uczynił z dwoma księgami Instytucji Gaiusa Teodor Dydyński. Druga połowa XX w. przyniosła tłumaczenie obu dzieł pióra Cezarego Kunderewicza (1982 i 1986), natomiast nieco później doskonałego przekładu Instytucji Gajańskich dokonał Władysław 
Rozwadowski. Nikt jednak nie pokusił się o kompleksowe tłumaczenie Digestów Justyniana, chociaż na uznanie zasługuje prowadzona od dłuższego czasu przez Annę Tarwacką akcja publikowania tłumaczenia poszczególnych tytułów z komentarzem na łamach „Zeszytów Prawniczych", a także tłumaczenie pierwszej księgi Digestów dokonane przez Bartosza Szolc-Nartowskiego. W związku z tym inicjatywa dr. Palmirskiego, aby dokonać przekładu całości Digestów zasługuje na najwyższą pochwałę, podobnie jak pomysł, aby do realizacji tego pomysłu zaangażować filologów klasycznych. Było to niezwykle fortunne pociągnięcie i teraz patrząc na efekty ich współpracy w postaci czterech opublikowanych tomów, trzeba stwierdzić, że ten mariaż filologii klasycznej i prawa rzymskiego jest niezwykle udanym i obiecującym na przyszłość związkiem.

Zamysł przełożenia Digestów na język polski ma pełne uzasadnienie. Bez żadnych wątpliwości bowiem przyswojenie ich polskiej kulturze prawnej jest wielkim i potrzebnym zadaniem. Należy przypomnieć, że Digesta obejmują całe materialne i procesowe rzymskie prawo prywatne. Zajmują się także prawem karnym, a ponadto niektórymi zagadnieniami prawa publicznego z zakresu ustroju i administracji państwa. Szczególną wagę mają rezultaty samodzielnej działalności prawników skierowanej przede wszystkim na odnajdywanie właściwych rozwiązań dla konkretnych przypadków. Są też źródłem wszystkich stosowanych współcześnie technik argumentacji prawniczej i sposobów uzasadniania przyjętych rozstrzygnięć. Umiejętności warsztatowe współczesnego prawnika nadal wynikają z tradycji rzymskiej nauki prawa, nawet jeśli on nie rozumie łaciny. Polski przekład Digestów ma zatem znaczenie dla wszystkich prawników, począwszy od studentów prawa, przez praktyków, skończywszy na prawodawcach.

Jak zatem ocenić dokonania Tomasza Palmirskiego i jego współpracowników? Na to pytanie każdy musi sobie sam odpowiedzieć. Ja nie ukrywam entuzjastycznego wręcz stosunku do tego przedsięwzięcia i kilkakrotnie dałem temu wyraz. Dobrze się stało, że autorzy tłumaczenia nie powielali maniery prof. Cezarego Kunderewicza, który w swoim przekładzie Instytucji Gaiusa starał się nadać mu taki 
kształt językowy, „dzięki któremu - cytuję - elementarne przecież dzieło Gaiusa byłoby ogólnie zrozumiałe i nie wymagało od polskiego czytelnika uprzedniego przygotowania specjalnego, tak jak zrozumiały był ogólnie chyba oryginał dla czytelników myślących i mówiących po łacinie". W rezultacie prof. Kunderewicz uznał, że techniczne terminy z prawa rzymskiego używane w nauce polskiej, tu znowu cytat: „występują do dzisiaj w postaci zewnętrznie tylko spolszczonej, pozostając w rzeczywistości wyrazami obcymi, niezrozumiałymi dla Polaka-nieprawnika bez objaśnień". I tu chyba popełnił błąd, gdyż te „zewnętrznie spolszczone łacińskie terminy łacińskie” wykazują dużo większą komunikatywność od ich rdzennie polskich odpowiedników. Stosowane bowiem od dłuższego czasu, weszły na trwałe do polskiego języka jurydycznego i posługują się nimi nie tylko romaniści, lecz także przedstawiciele innych dyscyplin prawniczych. Chodzi tu w szczególności o takie terminy techniczne, jak adopcja, kompensacja, windykacja, delikt itd. W imię puryzmu językowego prof. Kunderewicz zrezygnował nawet $\mathrm{z}$ tak rozpowszechnionego określenia jak ,kontrakt”, thumacząc zwrot ex contractu przez: „,z zaciągnięcia”. Powoduje to, że niekiedy, aby zrozumieć tłumaczenie, trzeba sięgnąć do oryginału łacińskiego, trudno bowiem nawet romaniście zrozumieć różnicę między „formalnym przyrzeczeniem” czyli stipulatio a „uroczystym przyrzeczeniem”, to jest sponsio, albo między „przyrzekającymi na rzetelność” czyli fidepromissores a „zapewniającymi na rzetelność” czyli fideiussores. Jak opowiadał prof. Henryk Kupiszewski, do metody takiego tłumaczenia na język polski za wszelką cenę, przekonał Cezarego Kunderewicza Jan Rezler, zasłużony i znany powszechnie autor podręcznika łaciny dla prawników. Oczywiście omawiany przekład Digestów pod redakcją Tomasza Palmirskiego ma zupełnie inny charakter, przy czym warto zauważyć, że w wielu przypadkach to tłumaczenie wymagało dużo pomysłowości, albowiem w prawie rzymskim występuje szereg terminów wręcz nieprzetłumaczalnych, jak np. actiones noxales, o których znakomity znawca łaciny prawniczej Kalb napisał, że język niemiecki nie zna odpowiadającego im terminu, czy też actio in factum i inne. Tłumacze użyli tu po prostu określenia „skargi noksalne” oraz ,skarga oparta 
na stanie faktycznym". Metoda ta jednak zawiodła w przypadku ius honorarium czy actio de peculio, przy których trudno byłoby stworzyć polski odpowiednik bez użycia rozbudowanej formuły opisowej. Sam swego czasu opracowując słownik dla prawników i historyków, stawałem wobec tego rodzaju problemu, ale moje zadanie było łatwiejsze, gdyż mogłem przy danym terminie podać dłuższe wyjaśnienie, na co zasadniczo nie ma miejsca w przekładzie tekstu źródłowego. Nawiasem mówiąc, $\mathrm{z}$ podobną trudnością, ale w odwrotnym kierunku, mamy też do czynienia w razie konieczności przetłumaczenia na łacinę słów współczesnych jak atom, drukarnia, komputer itd. Taka potrzeba zaistniała przy okazji soboru watykańskiego II, ale również np. w związku $\mathrm{z}$ nadawaniem przez radio fińskie dwa razy w tygodniu łacińskich relacji o bieżących wydarzeniach na świecie. Wówczas muszą ruszyć do akcji specjaliści od filologii klasycznej, którzy w oparciu o substrat językowy i zasady składni łacińskiej tworzą takie neologizmy, na ogół jednakże posługując się metodą opisową. Tak np. „hokej na lodzie”, to ludus pilae malleique super glacie czyli „zabawa piłeczką i kijkiem na lodzie". Podobną działalność prowadziliśmy swego czasu w Katedrze Prawa Rzymskiego Uniwersytetu Jagiellońskiego, gdy do prof. Wacława Osuchowskiego, przychodzili autorzy publikowanych na Uniwersytecie monografii, które zgodnie z przestrzeganą wówczas tradycją musiały mieć również tytuł łaciński. W takich sytuacjach prof. Osuchowski wołał nas, to znaczy mnie i Wiesława Litewskiego i dyskutowaliśmy nad optymalną wersją takiego tytułu. Z prawniczymi pracami na ogół nie mieliśmy większych kłopotów, ale niektóre, np. z ekonomii sprawiały nam trudności. Pamiętam, że w jednej z takich właśnie rozpraw występował termin ,probity”. Co to było już nie pomnę, zdaje się, że były to jakieś jednostki prawdopodobieństwa, którymi posługiwano się w ekonomii, ale głowy za to bym nie dał. W końcu doszliśmy do wniosku, że ten termin brzmi ,z łacińska” i zostawiliśmy go w takiej właśnie postaci.

Wracając natomiast do przekładu dr. Palmirskiego i jego zespołu, chciałbym podkreślić, że pomimo bardzo wysokiego mniemania o tym dziele, jak dałem temu wyraz wyżej, daleki jestem od stwierdzenia, że nie można mieć zastrzeżeń do tłumaczenia poszczególnych zwro- 
tów czy nawet pojedynczych terminów. Ostatecznie każdy przekład oznacza w jakimś sensie interpretację tekstu, a ta zależy od stanowiska autora i trzeba to uszanować. Jest jednak rzeczą zaskakującą, że Rada Wydziału Uniwersytetu Jagiellońskiego nie potrafiła docenić znaczenia tego osiągnięcia i odmówiła na tej podstawie wszczęcia dr. Palmirskiemu przewodu habilitacyjnego. Cóż, na jej usprawiedliwienie można dodać, że podobne problemy miał Otto Lenel, który ubiegał się o profesurę na podstawie rekonstrukcji 'Edictum perpetuum', natomiast uzasadnienie jakie padło przy tej okazji w Krakowie, że jest to dzieło o ogromnym znaczeniu dla kultury polskiej, ale nie zasługujące na to, by stanowić podstawę przewodu habilitacyjnego, świadczy o kompletnym nieporozumieniu. Ostatecznie do dzisiaj posługujemy się wydawnictwami źródłowymi z XIX w., podczas gdy monografie z tamtego okresu już dawno zostały uznane za przestarzałe. Sądzę, że przekład Digestów pod red. Tomasza Palmirskiego będzie służył nauce polskiej przez dziesiątki lat, dlatego życzę jego redaktorowi i całemu zespołowi wytrwałości i konsekwencji w realizacji tego monumentalnego przedsięwzięcia. Gdyby istniał romanistyczny Nobel, niewątpliwie ów zespół by nań zasłużył.

Janusz Sondel*

* Wyższa Szkoła Turystyki i Ekologii w Suchej Beskidzkiej 